\title{
Worldwide Esophageal Cancer Collaboration: neoadjuvant pathologic staging data
}

T. W. Rice, ${ }^{1}$ T. E. M. R. Lerut,${ }^{2}$ M. B. Orringer, ${ }^{3}$ L.-Q. Chen ${ }^{4}$ W. L. Hofstetter, ${ }^{5}$ B. M. Smithers, ${ }^{6}$ V. W. Rusch, J. van Lanschot, ${ }^{8}$ K. N. Chen, ${ }^{9}$ A. R. Davies, ${ }^{10}$ X. B. D'Journo, ${ }^{11}$ K. A. Kesler, ${ }^{12}$ J. D. Luketich, ${ }^{13}$ M. K. Ferguson, ${ }^{14}$ J. V. Räsänen, ${ }^{15}$ R. van Hillegersberg, ${ }^{16}$ W. Fang, ${ }^{17}$ L. Durand, ${ }^{18}$ W. H. Allum, ${ }^{19}$ I. Cecconello, ${ }^{20}$ R. J. Cerfolio, ${ }^{21}$ M. Pera, ${ }^{22}$ S. M. Griffin,${ }^{23}$ R. Burger,${ }^{24}$ J.-F. Liu, ${ }^{25}$ M. S. Allen ${ }^{26}$ S. Law,${ }^{27}$ T. J. Watson, ${ }^{28}$ G. E. Darling, ${ }^{29}$ W. J. Scott,${ }^{30}$ A. Duranceau, ${ }^{31}$ C. E. Denlinger, ${ }^{32}$ P. H. Schipper, ${ }^{33}$ H. Ishwaran, ${ }^{34}$ C. Apperson-Hansen, ${ }^{35}$ L. M. DiPaola, ${ }^{1}$ M. E. Semple, ${ }^{1}$ E. H. Blackstone ${ }^{1}$

${ }^{1}$ Cleveland Clinic, Cleveland, Ohio, USA, ${ }^{2}$ University Ziekenhuizen Leuven, Leuven, Belgium, ${ }^{3}$ University of Michigan, Ann Arbor, Michigan, USA, ${ }^{4}$ West China Hospital of Sichuan University, Chengdu, Sichuan, China, ${ }^{5}$ University of Texas MD Anderson Hospital, Houston, Texas, USA, ${ }^{6}$ University of Queensland, Princess Alexandra Hospital, Brisbane, Australia, ${ }^{7}$ Memorial Sloan-Kettering Cancer Center, New York, New York, USA, ${ }^{8}$ Erasmus Medical Center, Rotterdam, The Netherlands, ${ }^{9}$ Beijing Cancer Hospital, Beijing, China, ${ }^{10}$ Guy's \& St. Thomas' Hospitals, London, UK, ${ }^{11}$ Hôpital Nord, Marseille, France, ${ }^{12}$ Indiana University Medical Center, Indianapolis, Indiana, USA, ${ }^{13}$ University of Pittsburgh Medical Center, Pittsburgh, Pennsylvania, USA, ${ }^{14}$ Department of Surgery, The University of Chicago, Chicago, Illinois, USA, ${ }^{15}$ Helsinki University Hospital, Helsinki, Finland, ${ }^{16}$ University Medical Center Utrecht, Utrecht, The Netherlands, ${ }^{17}$ Shanghai Chest Hospital, Shanghai, China, ${ }^{18}$ Hospital de Clinicas, University of Buenos Aires, Buenos Aires, Argentina, ${ }^{19}$ Royal Marsden NHS Foundation Trust, London, UK, ${ }^{20}$ University of São Paulo, São Paulo, Brazil, ${ }^{21}$ University of Alabama at Birmingham, Birmingham, Alabama, USA, ${ }^{22}$ Hospital Universitario del Mar, Barcelona, Spain, ${ }^{23}$ University of Newcastle upon Tyne, Newcastle, UK, ${ }^{24}$ Groote Schuur Hospital, University of Cape Town, Cape Town, South Africa, ${ }^{25}$ Fourth Hospital of Hebei Medical University, Shijiazhuang, Hebei, China, ${ }^{26}$ Mayo Clinic, Rochester, Minnesota, USA, ${ }^{27}$ University of Hong Kong Medical Center, Queen Mary Hospital, Hong Kong, China, ${ }^{28}$ University of Rochester, Rochester, New York, USA,${ }^{29}$ Toronto General Hospital, Toronto, Ontario, Canada, ${ }^{30}$ Fox Chase Cancer Center, Philadelphia, Pennsylvania, USA, ${ }^{31}$ University of Montreal, Montreal, Quebec, Canada, ${ }^{32}$ Medical University of South Carolina, Charleston, South Carolina, USA, ${ }^{33}$ Oregon Health \& Science University, Portland, Oregon, USA, ${ }^{34}$ University of Miami, Miami, Florida, USA, and ${ }^{35}$ Case Western Reserve University, Cleveland, Ohio, USA

SUMMARY. To address uncertainty of whether pathologic stage groupings after neoadjuvant therapy (ypTNM) for esophageal cancer share prognostic implications with pathologic groupings after esophagectomy alone (pTNM), we report data-simple descriptions of patient characteristics, cancer categories, and non-risk-adjusted survival-for pathologically staged cancers after neoadjuvant therapy from the Worldwide Esophageal Cancer Collaboration (WECC). Thirty-three institutions from six continents submitted data using variables with standard definitions: demographics, comorbidities, clinical cancer categories, and all-cause mortality from first management decision. Of 7,773 pathologically staged neoadjuvant patients, 2,045 had squamous cell carcinoma, 5,686 adenocarcinoma, 31 adenosquamous carcinoma, and 11 undifferentiated carcinoma. Patients were older (61 years) men $(83 \%)$ with normal $(40 \%)$ or overweight $(35 \%)$ body mass index, 0-1 Eastern Cooperative Oncology Group performance status $(96 \%)$, and a history of smoking $(69 \%)$. Cancers were ypT0 $(20 \%)$, ypT1 $(13 \%)$, ypT2 (18\%), ypT3 (44\%), ypNo (55\%), ypM0 (94\%), and G2-G3 (72\%); most involved the distal esophagus (80\%). Non-riskadjusted survival for yp categories was unequally depressed, more for earlier categories than later, compared with

Address correspondence to: Thomas W. Rice, MD, Department of Thoracic and Cardiovascular Surgery, Cleveland Clinic; 9500 Euclid Avenue/Desk JJ-40; Cleveland, OH 44195, USA. Email: ricet@ccf.org

Author contributions: Conception or design of the experiment(s), or collection and analysis or interpretation of data: All authors. Drafting the manuscript or revising its intellectual content: T.W. Rice, C. Apperson-Hansen, and E. H. Blackstone. Approval of the final version of the submitted manuscript: All authors. 
equivalent categories from prior WECC data for esophagectomy-alone patients. Thus, survival of patients with ypT0-2N0M0 cancers was intermediate and similar regardless of ypT; survival for ypN+ cancers was poor. Because prognoses for ypTNM and pTNM categories are dissimilar, prognostication should be based on separate ypTNM categories and groupings. These data will be the basis for the 8th edition cancer staging manuals following risk adjustment for patient, cancer, and treatment characteristics and should direct 9th edition data collection.

$K E Y$ WORDS: cancer staging, chemotherapy, prognostication, radiotherapy, survival.

\section{INTRODUCTION}

Esophageal cancer staging in the 7th edition AJCC and UICC cancer staging manuals ${ }^{1,2}$ was based on pathologic stage (pTNM) after esophagectomy alone, derived from Worldwide Esophageal Cancer Collaboration (WECC) data. ${ }^{3}$ However, today a minority of advanced-stage esophageal cancers are treated by esophagectomy alone; some form of combined modality therapy (neoadjuvant therapy) is nearly always used. Pathologic stage after neoadjuvant therapy (ypTNM), by tradition, shares pathologic stage groupings with pTNM. However, whether the prognostic significance of pTNM staging is shared with ypTNM is uncertain.

To address this uncertainty, a six-continent collaborative effort - WECC - was mounted to collect patient and esophageal cancer characteristics and all-cause mortality following neoadjuvant therapy to (i) test the hypothesis that pathologic classifications after neoadjuvant therapy share the same prognostic implications as those after esophagectomy alone; (ii) facilitate posttreatment prognostication; and (iii) develop the first data-driven ypTNM recommendations for the 8th edition cancer staging manuals after risk adjustment. In this article, we simply report the descriptive data on patient and cancer characteristics of individuals with pathologically staged cancers after neoadjuvant therapy, and non-risk-adjusted survival analyses that begin to address these aims.

\section{PATIENTS AND METHODS}

Data

In 2012, institutions worldwide were invited to participate in WECC, aimed at constructing refined data-driven esophageal cancer staging for the 8th edition of the cancer staging manuals. ${ }^{4}$ Data were requested in completely de-identified form (Health Insurance Portability and Accountability Act research standards) for analysis, using a set of required variables with standard definitions. Local ethics-board approval of the databases and data-use agreements were executed with Cleveland Clinic. Variables included demographics, comorbidities, cancer categories, cancer treatment, and time- related outcomes. The Case Cancer Institutional Review Board of Case Western Reserve University and the Cleveland Clinic Institutional Review Board approved the entire project. This paper reports results of pathologic data of patients receiving neoadjuvant therapy from 33 institutions whose data were submitted by September 30, 2014, and were cleaned and adjudicated (Appendix).

\section{Patients}

A total of 7,773 patients with epithelial esophageal cancers had pathologic staging data after neoadjuvant therapy. The majority were older men with normal or overweight body mass index, no weight loss, and 0-1 Eastern Cooperative Oncology Group (ECOG) performance status (Table 1 and Supporting Information Table S1). Comorbidities were present in a minority of patients, with cardiopulmonary comorbidities predominating. Although six continents are represented, most patients were treated in North America or Europe.

Compared to patients with pure squamous cell carcinoma (SCC), those with pure adenocarcinoma were far less likely to be female, but more likely to be larger, have an ECOG performance status of 1 rather than 0 , have diabetes, better forced expiratory volume in $1 \mathrm{sec}-$ ond, and be from the West (Table 1). Age and cardiovascular morbidity were similar.

\section{Treatment}

Chemoradiotherapy was the predominant neoadjuvant therapy (Table 2 and Supporting Information Table S2). Approximately one fifth of patients received neoadjuvant chemotherapy, and one tenth of those with pure SCC received radiotherapy. Less invasive esophagectomy was used in few patients. Number of lymph nodes resected was highly variable. Fifteen percent of patients received postoperative adjuvant therapy.

\section{Endpoint}

The study endpoint was all-cause mortality from first management decision. Median potential follow-up, ${ }^{5}$ if there were no deaths, was 8.2 years $(25 \%$ $>12.9$ years, $10 \%>17.9$ years), but considering deaths in this elderly population with a rapidly

(c) 2016 International Society for Diseases of the Esophagus 
Table 1 Characteristics of patients receiving neoadjuvant therapy for pure squamous cell carcinoma and pure adenocarcinoma of the esophagus

\begin{tabular}{|c|c|c|c|c|}
\hline \multirow[b]{2}{*}{ Characteristic } & \multicolumn{2}{|c|}{$\begin{array}{l}\text { Squamous Cell } \\
\text { Carcinoma } \\
\text { (total } n=2,045 \text { ) }\end{array}$} & \multicolumn{2}{|c|}{$\begin{array}{l}\text { Adenocarcinoma } \\
\text { (total } n=5,686 \text { ) }\end{array}$} \\
\hline & $n^{*}$ & $\begin{array}{l}\text { No. }(\%) \text { or } \\
\text { Mean } \pm \text { SD }\end{array}$ & $n^{*}$ & $\begin{array}{l}\text { No. }(\%) \text { or } \\
\text { Mean } \pm \text { SD }\end{array}$ \\
\hline \multicolumn{5}{|l|}{ Demographics } \\
\hline Age (y) & 2,000 & $61 \pm 9.4$ & 5,513 & $61 \pm 9.8$ \\
\hline Female & 2,045 & $678(33)$ & 5,686 & $658(12)$ \\
\hline $\begin{array}{l}\text { Body mass } \\
\text { index }\left(\mathrm{mg} / \mathrm{kg}^{2}\right)\end{array}$ & 1,053 & $23 \pm 4.1$ & 3,222 & $28 \pm 5.2$ \\
\hline Weight loss (kg) & 1,067 & $2.6 \pm 6.0$ & 2,532 & $3.6 \pm 7.1$ \\
\hline \multicolumn{5}{|l|}{ Comorbidities } \\
\hline $\begin{array}{l}\text { ECOG performance } \\
\text { status }\end{array}$ & 571 & & 1,891 & \\
\hline 0 & & $289(51)$ & & $660(35)$ \\
\hline 1 & & $238(42)$ & & $1,163(62)$ \\
\hline 2 & & $31(5.4)$ & & $54(2.9)$ \\
\hline 3 & & $12(2.1)$ & & $12(0.63)$ \\
\hline 4 & & $1(0.18)$ & & $2(0.11)$ \\
\hline Diabetes & 1,798 & $94(5.2)$ & 5,091 & $638(13)$ \\
\hline IDDM & 1,765 & $16(0.91)$ & 4,876 & $67(1.4)$ \\
\hline NIDDM & 1,765 & $45(2.5)$ & 4,876 & $356(7.3)$ \\
\hline $\begin{array}{c}\text { Coronary artery } \\
\text { disease }\end{array}$ & 915 & $109(12)$ & 3,323 & $486(15)$ \\
\hline Arrhythmia & 686 & $23(3.4)$ & 1,976 & $43(2.2)$ \\
\hline Hypertension & 1,351 & $338(25)$ & 3,688 & $1,084(29)$ \\
\hline $\begin{array}{l}\text { Peripheral arterial } \\
\text { disease }\end{array}$ & 1,102 & $50(4.5)$ & 3,363 & $84(2.5)$ \\
\hline Smoker & 1,370 & $1038(76)$ & 4,324 & $2,902(67)$ \\
\hline Past & 1,075 & $444(41)$ & 3,527 & $1,552(44)$ \\
\hline Current & 1,075 & $299(28)$ & 3,527 & $553(16)$ \\
\hline $\begin{array}{l}\text { FEV1 (\% of } \\
\text { predicted) }\end{array}$ & 903 & $90 \pm 20$ & 2,530 & $95 \pm 19$ \\
\hline $\begin{array}{l}\text { FVC (\% of } \\
\text { predicted) }\end{array}$ & 657 & $99 \pm 18$ & 1,411 & $99 \pm 17$ \\
\hline $\begin{array}{l}\text { Creatinine } \\
(\mu \mathrm{mol} / \mathrm{L})\end{array}$ & 316 & $73 \pm 19$ & 667 & $77 \pm 20$ \\
\hline $\begin{array}{l}\text { Bilirubin } \\
(\mu \mathrm{mol} / \mathrm{L})\end{array}$ & 259 & $12 \pm 5.4$ & 416 & $9.8 \pm 7.5$ \\
\hline $\begin{array}{l}\text { Decade of } \\
\text { treatment }\end{array}$ & 2,045 & & 5,686 & \\
\hline 1970-1979 & & $60(2.9)$ & & $6(0.11)$ \\
\hline 1980-1989 & & $197(9.6)$ & & $137(2.4)$ \\
\hline 1990-1999 & & $424(21)$ & & $826(15)$ \\
\hline $2000-2009$ & & 977 (48) & & $3,316(58)$ \\
\hline 2010-2014 & & 387 (19) & & $1,401(25)$ \\
\hline Continent & 2,045 & & 5,686 & \\
\hline North America & & $973(48)$ & & $3,880(68)$ \\
\hline Europe & & $568(28)$ & & 1,367 (24) \\
\hline Asia & & $408(20)$ & & $51(0.9)$ \\
\hline Australia & & 94 (4.6) & & $379(6.7)$ \\
\hline South America & & $1(0.049)$ & & $6(0.11)$ \\
\hline Africa & & $1(0.049)$ & & $3(0.053)$ \\
\hline
\end{tabular}

Patient characteristics of those with adenosquamous and undifferentiated carcinoma are shown in Supporting Information Table S1.

*Patients with data available.

ECOG, Eastern Cooperative Oncology Group; FEV1 (\%), forced expiratory volume in 1 second (percent of predicted); FVC $(\%)$, forced vital capacity (percent of predicted); IDDM, insulindependent diabetes mellitus; NIDDM, non-insulin-dependent diabetes mellitus; SD, standard deviation.

lethal cancer, overall median follow-up was 1.6 years; median follow-up for surviving patients was 1.8 years, with $25 \%$ followed more than 4.1 years and $10 \%$ more than 6.8 years.

(C) 2016 International Society for Diseases of the Esophagus

\section{Data analysis}

For analysis, patients with adenosquamous and undifferentiated carcinoma (Supporting Information Tables S1 and S2) were considered in both SCC and adenocarcinoma data sets. Survival was estimated by the Kaplan-Meier method, and these estimates are accompanied by $68 \%$ confidence limits, equivalent to \pm 1 standard error. The hazard function for death was estimated by a parametric temporal decomposition method $^{6}$ (for additional details, see http://www.lerner. ccf.org/qhs/software/hazard). Continuous variables are summarized by means and standard deviation and categorical variables by frequency and percentage.

\section{RESULTS}

\section{Neoadjuvant pathologic cancer categories}

Histopathologic cell type was SCC in 2,045, adenocarcinoma in 5,686, adenosquamous carcinoma in 31 , and undifferentiated carcinoma in 11. Upon resection, the majority of SCCs were confined to the esophageal wall (ypT2 or less); there was an equal distribution within (ypT2 or less) and beyond (ypT3-T4) the esophageal wall for adenocarcinomas (Table 3 and Supporting Information Table S3). There was no residual cancer (ypT0N0M0) in $25 \%$ of SCCs and $13 \%$ of adenocarcinomas. Most cancers were free of regional lymph node metastasis (ypN0). Frequency of number of positive lymph nodes progressively decreased for

Table 2 Treatment received by patients with pure squamous cell carcinoma and pure adenocarcinoma of the esophagus

\begin{tabular}{lcc}
\hline & $\begin{array}{c}\text { Squamous cell } \\
\text { carcinoma } \\
(n=2,045)\end{array}$ & $\begin{array}{c}\text { Adenocarcinoma } \\
(n=5,686) \\
\text { No. }(\%)\end{array}$ \\
Treatment & No. $(\%)$ & \\
\hline Neoadjuvant & & \\
Chemoradiotherapy & $1,372(67)$ & $4,242(76)$ \\
Chemotherapy & $454(22)$ & $1,306(23)$ \\
Radiotherapy & $211(10)$ & $62(1.1)$ \\
Unknown & 8 & 76 \\
Resection & & \\
Esophagectomy & $2,045(100)$ & $5,686(100)$ \\
Less invasive & $56(2.7)$ & $350(6.2)$ \\
Lymph nodes resected & $17(1.8)$ & $103(3.4)$ \\
0 & $71(7.4)$ & $246(8.1)$ \\
$1-5$ & $147(15)$ & $432(14)$ \\
6-10 & $356(37)$ & $1,106(36)$ \\
$11-20$ & $232(24)$ & $704(23)$ \\
$21-30$ & $131(14)$ & $446(15)$ \\
$>30$ & 1,091 & 2,649 \\
Unknown & & \\
Resection Margin & $1,851(91)$ & $5,086(89)$ \\
R0 & $149(7.3)$ & $425(7.5)$ \\
R1 & $45(2.2)$ & $175(3.1)$ \\
R2 & & \\
Adjuvant & $62(3.0)$ & $420(7.4)$ \\
Chemoradiotherapy & $210(10)$ & $375(6.6)$ \\
Chemotherapy & $43(2.1)$ & $60(1.1)$ \\
Radiotherapy & & \\
\hline
\end{tabular}

Treatment received by patients with adenosquamous and undifferentiated carcinoma are shown in Supporting Information Table S2. 
Table 3 Pathologic cancer categories of patients receiving neoadjuvant therapy for pure squamous cell carcinoma and adenocarcinoma of the esophagus

\begin{tabular}{|c|c|c|}
\hline Category & $\begin{array}{c}\text { Squamous } \\
\text { cell } \\
\text { carcinoma } \\
(\mathrm{n}=2,045) \\
\text { No. }(\%)\end{array}$ & $\begin{array}{c}\text { Adenocarcinoma } \\
(\mathrm{n}=5,686) \\
\text { No. }(\%)\end{array}$ \\
\hline \multicolumn{3}{|l|}{$y p T$} \\
\hline урТ0 & $604(30)$ & $896(17)$ \\
\hline ypTis & $6(0.30)$ & $13(0.24)$ \\
\hline ypT1 & $220(11)$ & $752(14)$ \\
\hline урT2 & $363(18)$ & 990 (19) \\
\hline урT3 & $699(35)$ & $2,542(48)$ \\
\hline урT4a & $99(4.8)$ & $121(2.3)$ \\
\hline уртX & 54 & 372 \\
\hline \multicolumn{3}{|l|}{$y p N$} \\
\hline урNo & $1,349(65)$ & $2,900(51)$ \\
\hline ypN+ & $696(34)$ & 2,757 (49) \\
\hline ypN1 & $375(64) *$ & $1,138(48) \dagger$ \\
\hline ypN2 & $157(27)^{*}$ & $748(32) \dagger$ \\
\hline ypN3 & $54(9.2)^{*}$ & $466(20) \dagger$ \\
\hline ypNX & 6 & 29 \\
\hline \multicolumn{3}{|l|}{$\begin{array}{l}\text { Number of } \\
\text { positive nodes }\end{array}$} \\
\hline 0 & $1,343(70)$ & $2,900(55)$ \\
\hline 1 & $252(13)$ & $672(13)$ \\
\hline & $123(6.4)$ & 466 (8.9) \\
\hline 3 & $60(3.1)$ & $273(5.2)$ \\
\hline 4 & $50(2.6)$ & $206(3.9)$ \\
\hline 5 & 31 (1.6) & $133(2.5)$ \\
\hline 6 & $16(0.83)$ & $136(2.6)$ \\
\hline 7 or more & $54(2.8)$ & 466 (8.9) \\
\hline Unknown & 116 & 434 \\
\hline ECLNI & $48(22) \S$ & 174 (43)ף \\
\hline $\begin{array}{l}\text { Lymphovascular } \\
\text { invasion }\end{array}$ & $211(28) \dagger \dagger$ & $736(37)+t$ \\
\hline \multicolumn{3}{|l|}{ ypM } \\
\hline урМ0 & 1,931 (94) & $5,334(94)$ \\
\hline \multirow{2}{*}{\multicolumn{3}{|c|}{ Grade $^{\ddagger}$}} \\
\hline & & \\
\hline ypG1 & $692(42)$ & $1,012(23)$ \\
\hline ypG2 & $523(32)$ & $1,476(33)$ \\
\hline ypG3 & $431(26)$ & $1,960(44)$ \\
\hline ypGX & 399 & 1,238 \\
\hline \multicolumn{3}{|l|}{ Location } \\
\hline ypUpper & 297 (16) & $31(0.70)$ \\
\hline ypMiddle & $850(47)$ & $141(3.0)$ \\
\hline ypLower & $676(37)$ & $4,526(96)$ \\
\hline ypLocationX & 222 & 988 \\
\hline
\end{tabular}

Neoadjuvant pathologic cancer categories of those with adenosquamous and undifferentiated carcinoma are shown in Supporting Information Table S3.

*Data available for 586 patients. $\dagger$ Data available for 2,352 patients. †G4 carcinomas are reported in Supporting Information Table S3. $\S$ Data available for $221 \mathrm{ypN}+$ patients. ๆData available for 402 ypN + patients. ††Data available for 743 patients. \$Data available for 1,984 patients. ECLNI, extracapsular lymph node invasion.

both histopathologic cell types, with $2.8 \%$ of SCCs and $8.9 \%$ of adenocarcinomas having seven or more positive nodes. Extracapsular lymph node invasion (ECLNI) was infrequently recorded, but present in $22 \%$ of $\mathrm{N}+$ SCCs and $43 \%$ of $\mathrm{N}+$ adenocarcinomas. Lymphovascular invasion was discovered in approximately one third of cancers. Few cancers had distant metastases (ypM). The majority of SCCs were G1-2 (74\%); adenocarcinomas were less differentiated (77\% G2-3). The middle thoracic esophagus was the most common location, followed by the lower thoracic esophagus in SCC, with a minority $(16 \%)$ in the upper thoracic esophagus. Cancer location was almost exclusively in the lower thoracic esophagus for adenocarcinoma.

\section{Non-risk-adjusted survival}

Overall survival was $98 \%, 75 \%, 33 \%$, and $21 \%$ at 30 days, 1,5 , and 10 years, respectively, and was similar for SCC and adenocarcinoma (Supporting Information Fig. S1). Risk of death peaked within months of the first management decision for SCC and within a year for adenocarcinoma, then gradually decreased and plateaued by about 5 years to a near constant rate of $8 \%$ per year for both (Supporting Information Fig. S2).

Neoadjuvant pathologic categories (ypTNM). Survival was similar for squamous cell cancers confined to the wall (ypT2 or less), but poor, distinctive, and stratified for ypT3 and ypT4a cancers (Fig. 1A). Survival had a similar pattern for adenocarcinoma, except that ypT2 was distinctive and stratified (Fig. 1B). Survival decreased monotonically and distinctively with presence of regional lymph node metastases (ypN), except for ypN2 and ypN3 SCCs (Fig. 2). Survival diminished markedly with increasing number of regional lymph nodes positive for cancer (Supporting Information Fig. S3). For ypN0 cancers, survival decreased distinctively and monotonically only for ypT3 and ypT4a cancers (Fig. 3). Survival for ypN + cancers was poor and not well stratified for SCC (Fig. 4A), but was distinctive and stratified for adenocarcinoma (Fig. 4B). Survival decreased with presence of distant metastases (ypM) (Fig. 5).

Other cancer categories. Survival was distinctive for G1 SCC and for G1-3 adenocarcinomas, but generally stratified for both cancers (Supporting Information Fig. S4). Survival was not distinctive or stratified by location in the esophagus (Supporting Information Fig. S5).

Other characteristics. Survival did not stratify well by age, particularly for adenocarcinoma (Supporting Information Fig. S6). Survival was worse for men with SCC than women (Supporting Information Fig. S7A), but similar between the sexes for adenocarcinoma (Supporting Information Fig. S7B).

Treatment. Survival was similar for patients receiving neoadjuvant chemoradiotherapy or chemotherapy, but worse for those receiving radiotherapy (Supporting Information Fig. S8). Patients receiving adjuvant therapy had better early survival, but by 2 years it was slightly worse compared with those who did not (Supporting Information Fig. S9). Survival was not better with increasing number of lymph nodes resected

(C) 2016 International Society for Diseases of the Esophagus 

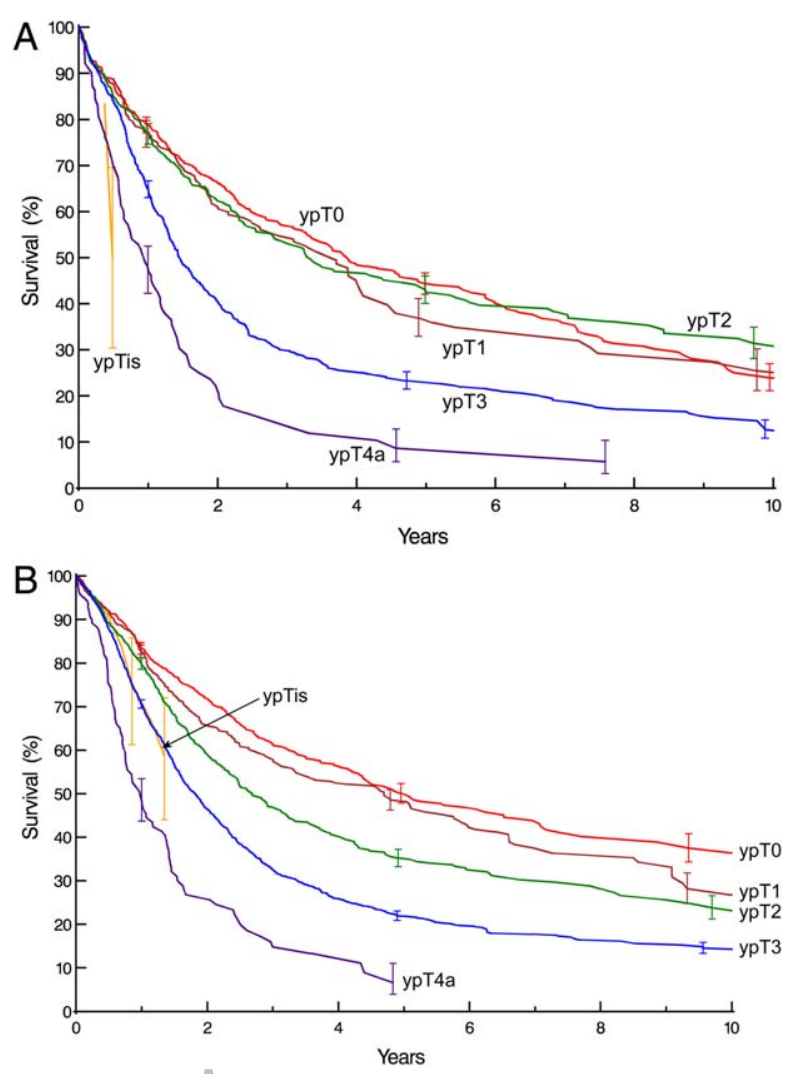

Fig. 1 Survival by ypT category. Kaplan-Meier estimates accompanied by vertical bars representing $68 \%$ confidence limits, equivalent to \pm 1 standard error. A. Squamous cell carcinoma. B. Adenocarcinoma.

(Supporting Information Fig. S10), and was best for R0 and similar for R1 or R2 resections (Supporting Information Fig. S11).

\section{DISCUSSION}

\section{Appropriateness of shared stage groupings}

Comparing survival of patients receiving neoadjuvant therapy to that of patients with equivalent pathologic categories receiving surgery alone, ${ }^{3,7}$ it is evident that prognostic implications for neoadjuvant categories (ypTNM) differ from those of equivalent pathologic categories ( $p$ TNM). Survival of node-negative patients receiving neoadjuvant therapy (ypN0) is worse than equivalently pathologically categorized patients receiving esophagectomy alone ( $\mathrm{pN} 0)$; prognosis of nodepositive patients receiving neoadjuvant therapy $(\mathrm{ypN}+)$ is either worse or no better than equivalent patients receiving esophagectomy alone $(\mathrm{pN}+)$. Separate or adjusted stage groupings for patients receiving neoadjuvant therapy based on prognosis would be ideal.

\section{Principal findings}

Complete response of the primary cancer (ypT0N0M0) does not ensure good survival. Patients with cancer confined to the wall or less (ypT0-2) and (c) 2016 International Society for Diseases of the Esophagus no regional lymph node metastasis (ypN0) have intermediate survival, which is similar across ypT. Persistence of cancer outside the esophageal wall (ypT3/T4a) in node-negative patients and failure to sterilize regional lymph node metastasis $(\mathrm{ypN}+)$ is associated with poor survival. In these patients, neoadjuvant therapy has a small survival benefit or may be harmful, depending on the extent of downstaging of $\mathrm{cN}+$ and amount of toxicity. The effect of non-anatomic cancer categories (histologic grade and location) on survival is less evident after neoadjuvant therapy than after esophagectomy alone.

\section{WECC and data assemblage}

WECC data for the 7th edition staging manuals was based on pathologic staging of patients undergoing esophagectomy alone. ${ }^{3}$ This new WECC effort included collecting pathologic staging data for all patients undergoing neoadjuvant therapy and for those who received postoperative adjuvant therapy. This is a unique data set representing the current state of the art in treatment of advanced-stage esophageal cancer, which has replaced esophagectomy alone for such patients. The number of patient characteristics was greater and the data more complete than in the prior WECC effort. ${ }^{3}$ Thus, this was a global effort of considerable magnitude across geography, institutions, patient characteristics, cancer categories, and
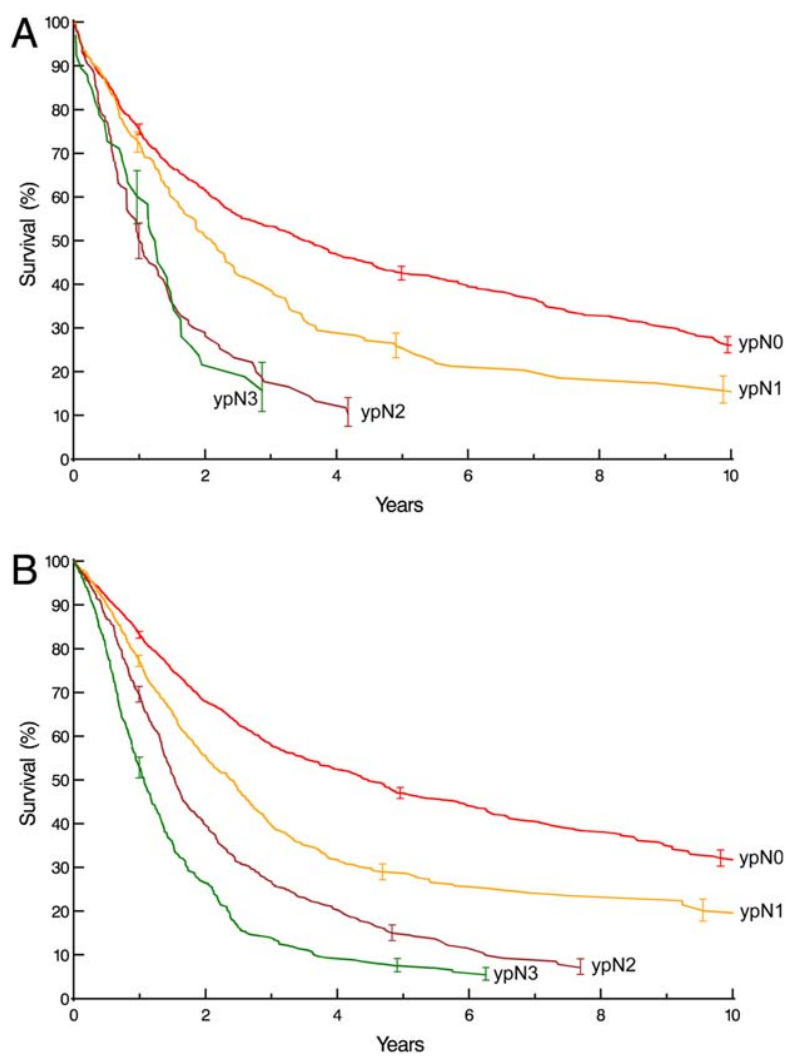

Fig. 2 Survival by ypN category. Format is as in Fig. 1. A. Squamous cell carcinoma. B. Adenocarcinoma. 

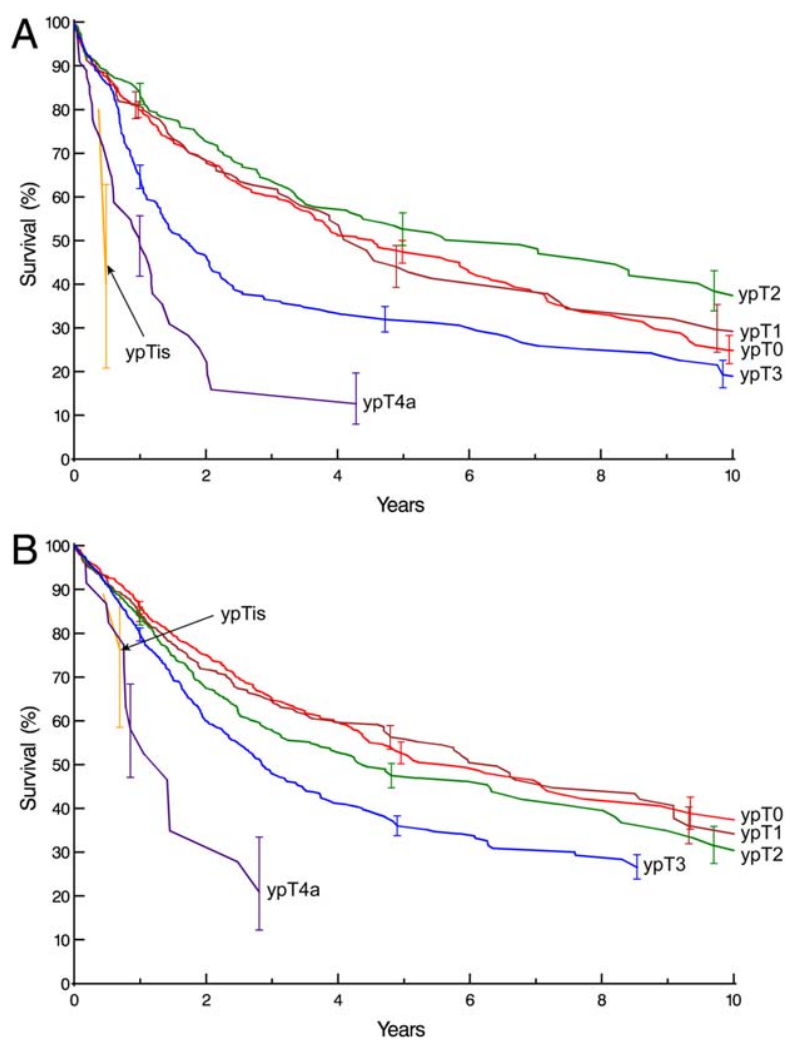

Fig. 3 Survival by ypT category for ypN0 cancers. Format is as in Fig. 1. A. Squamous cell carcinoma. B. Adenocarcinoma.

treatments. These data will serve as the basis for developing the first data-driven esophageal cancer ypTNM recommendations for the 8th edition cancer staging manuals after risk adjustment for all these variables.

\section{Neoadjuvant patient characteristics}

Patients receiving neoadjuvant therapy for esophageal cancer are highly selected. Mean age was less and ECOG performance status better than for the average patient in the WECC database. ${ }^{4}$ However, comorbidities were numerous, clinically significant, and similar to those in the complete WECC database; collection of these data is essential for risk adjustment of all-cause mortality.

\section{Treatment}

Chemoradiotherapy was the principal neoadjuvant therapy. Chemotherapy was administered to approximately a fifth of the patients. Radiotherapy was uncommon, particularly in adenocarcinoma patients. Despite inclusion of many institutions with expertise in less invasive esophagectomy, the vast majority of neoadjuvant patients had a traditional esophagectomy approach. There was significant variability in number of lymph nodes resected, explained in part by the difficulty in performing lymphadenectomy in a pre-treated field. Postoperative adjuvant therapy was administered to approximately $15 \%$ of patients.

\section{Neoadjuvant pathologic cancer categories}

The majority of primary cancers were sterilized or confined to the esophageal wall (ypT0-2), and the majority of regional lymph nodes were free of cancer (ypN0). However, there was a sufficient number of patients to provide a spectrum of pathologically staged esophageal cancer patients undergoing neoadjuvant therapy. Frequency of histologic grade in decreasing order for SCC was G1, G2, and G3; the inverse was reported for adenocarcinoma. Few patients had G4 cancers, reflecting their rarity. Location was predominately the lower thoracic esophagus in adenocarcinoma patients; there were few patients with adenocarcinoma of the middle thoracic esophagus, and rarely, of the upper thoracic esophagus. The distribution of location for SCC, although predominantly in the middle and lower thoracic esophagus, will be sufficient to permit analysis of the effect of location on risk-adjusted survival. No patients with cervical esophageal cancer were included in the data.

\section{Non-risk-adjusted survival}

The endpoint for this study was all-cause mortality. ${ }^{3}$ This hard endpoint has been shown to provide a truer reflection of death due to cancer than the softer endpoint of disease-specific mortality. ${ }^{8-10}$

Regardless of histopathologic cell type, survival curves were unequally depressed, more for earlier
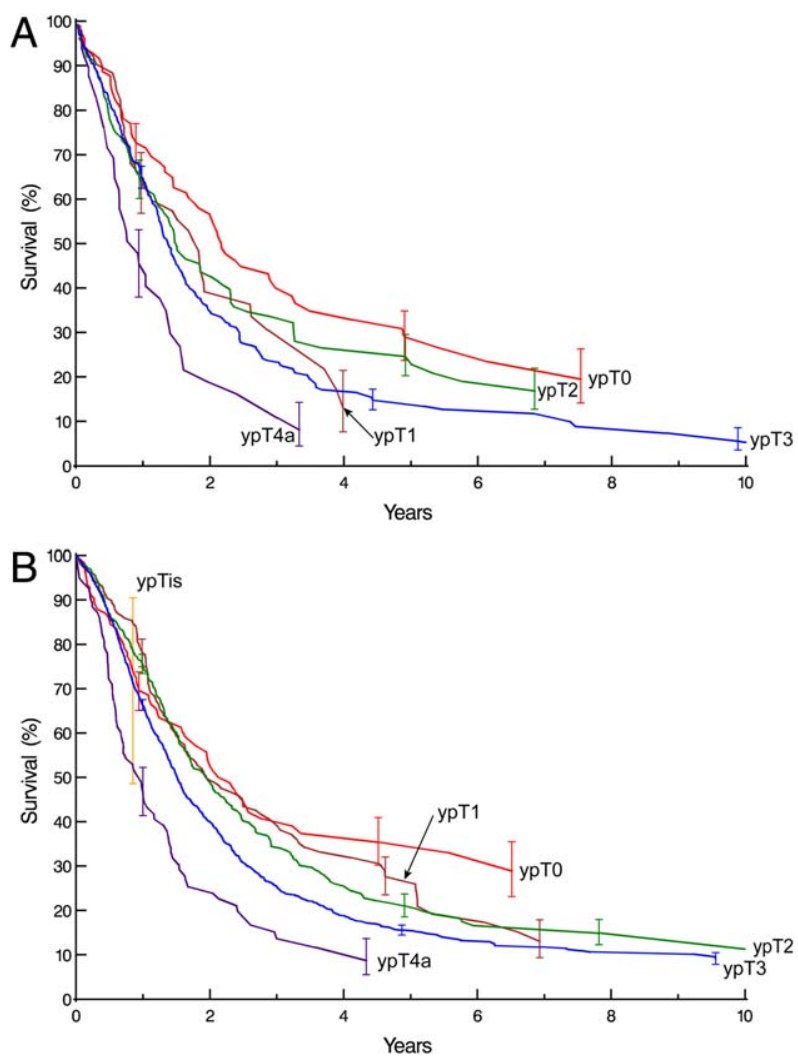

Fig. 4 Survival by ypT category for ypN + cancers. Format is as in. Fig. 1. A. Squamous cell carcinoma. B. Adenocarcinoma.

(C) 2016 International Society for Diseases of the Esophagus 

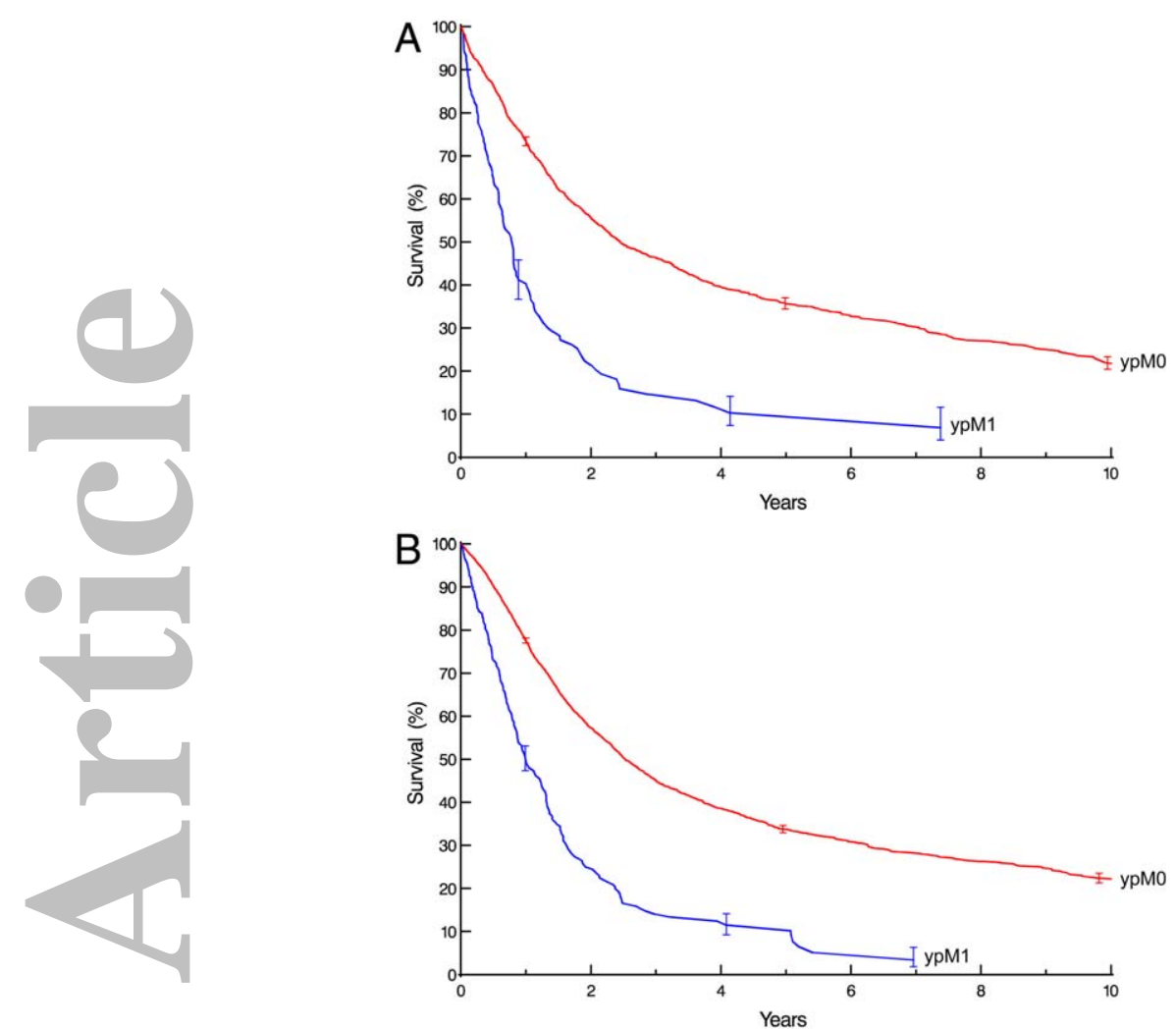

Fig. 5 Survival by ypM category. Format is as in Fig. 1. A. Squamous cell carcinoma. B. Adenocarcinoma.

cancer classifications than for later, compared with pathologic staging after esophagectomy alone. ${ }^{3}$ Survival was much less distinctive for ypT, grade, and location than seen in pathologically staged cancers treated by esophagectomy alone. ${ }^{3}$ Survival was substantially different for ypN0 patients versus those with $\mathrm{N}+$. Similarly, survival was substantially different for ypM0 patients versus those with ypM + . The survival benefit of lower histologic grade is less evident in patients with ypTNM cancers than in those with similarly staged $\mathrm{pTNM}$ cancers. ${ }^{3}$

Survival was homogeneous for ypN0 patients for cancer confined to the wall (ypTis-2, ypT1, and ypT2) or those sterilized (ypT0). Survival was poor for ypN+ patients regardless of ypT and number of positive nodes for SCC. Adenocarcinoma patients with ypN1 cancers had better survival compared with ypN2-3 patients.

Radiation therapy is less effective than chemoradiotherapy or chemotherapy. Non-risk-adjusted survival was similar for chemotherapy and chemoradiotherapy; however, risk adjustment is necessary to confirm similarity. Further, non-risk-adjusted survival for patients receiving adjuvant therapy was similar to that of patients not receiving it, a finding also requiring risk adjustment to confirm.

\section{Strengths and limitations}

Currently, this is the best attempt at providing worldwide pathologic esophageal cancer staging data in (c) 2016 International Society for Diseases of the Esophagus patients receiving neoadjuvant therapy. However, patient selection and treatment delivery were not uniform among centers or continents, and these heterogeneities are reflected in heterogeneous survival. Patients treated in North America and Europe predominated. Unlike most registry data, WECC collected more patient and cancer characteristics, specific treatment and start dates were known in all, and follow-up data were available in all. However, not all variables were recorded in all patients.

Limitations include variability of clinical staging, pathologic and staging definitions, and neoadjuvant treatment protocols over time. Where possible, data variables were updated to 7 th edition definitions. Stage grouping analyses with risk adjustment will potentially minimize the effect of time. However, changing neoadjuvant treatment over time can only be coarsely corrected for, because there are minimal details about treatment delivered.

An additional limitation of this pure data presentation is that it does not account for patient variables that affect all-cause mortality; the interplay among TNM, histopathologic cell type, histologic grade, and cancer location, in part due to the unique lymphatic anatomy of the esophagus; and the confounding of treatment effects, temporal factors, etiology, diagnosis, and clinical decision making around the world. This analysis does not account for patients' initial cancer characteristics and variable downstaging. 


\section{Clinical implications}

These data reinforce the need for improved clinical staging so that fewer cancers are incorrectly staged as advanced (overstaged), needlessly exposing patients to the toxicity of neoadjuvant therapy. If this therapy is to be successful, it is necessary to identify those cancers that will respond to a neoadjuvant approach and spare patients with non-responding cancers (persistent disease invading outside the esophageal wall and persistent nodal metastasis) from neoadjuvant therapy. There is need for targeted, cancer-specific therapy. Hopefully, the shotgun approach of neoadjuvant therapy is temporary and does not represent the future.

\section{CONCLUSIONS}

These data demonstrate that patients receiving neoadjuvant therapy do not have equivalent survival to patients with the same pathologic category undergoing esophagectomy alone. For them, separate stage groupings will be used in the 8 th edition cancer staging manuals.

Prognostication is possible, but survival is reduced from what has been classically quoted from stage groupings based on esophagectomy alone. Persistent regional lymph node metastases $(\mathrm{ypN}+)$ portend poor survival, and sterilization of metastatic regional lymph nodes (ypN0) does not equate with cure. Patients with ypN0 cancers confined to the esophageal wall or those with complete response have an intermediate survival regardless of ypT.

These data will be used to prepare for the 8th edition cancer staging manuals after risk adjustment for many confounding variables. They should direct data collection for the 9 th edition. This is a milestone in the pathologic staging of esophageal cancer patients receiving neoadjuvant therapy and provides a direction for future advancements.

\section{Acknowledgments}

The authors thank Brian Kohlbacher for assistance with figure annotation and Tess Parry for editorial assistance.

\section{References}

1 Edge S B, Byrd D R, Compton C C, Fritz A G, Greene F L, Trotti A, (eds). American Joint Committee on Cancer Staging Manual, 7th ed. New York: Springer-Verlag, 2010.

2 Sobin L H, Gospodarowicz M K, Wittekind C, (eds). TNM Classification of Malignant Tumours. International Union against Cancer, 7th ed. Oxford, England: Wiley-Blackwell, 2009.

3 Rice T W, Rusch V W, Apperson-Hansen C et al. Worldwide Esophageal Cancer Collaboration. Dis Esophagus 2009; 22: 1-8.

4 Rice T W, Apperson-Hansen C, DiPaola L M et al. Worldwide Esophageal Cancer Collaboration: Clinical staging data. Dis Esophagus 2016 (forthcoming).
5 Goldman A I. Eventcharts: Visualizing survival and other timed-event data. Am Stat 1992; 46: 13-8.

6 Blackstone E H, Naftel D C, Turner M E Jr. The decomposition of time-varying hazard into phases, each incorporating a separate stream of concomitant information. J Am Stat Assoc 1986; 81: 615-24.

7 Rice T W, Rusch V W, Ishwaran H, Blackstone E H. Cancer of the esophagus and esophagogastric junction: data-driven staging for the seventh edition of the American Joint Committee on Cancer/International Union against Cancer Cancer Staging Manuals. Cancer 2010; 116: 3763-73.

8 van Leeuwen P J, Kranse R, Hakulinen T et al. Disease-specific mortality may underestimate the total effect of prostate cancer screening. J Med Screen 2010; 17: 204-10.

9 Black W C, Haggstrom D A, Welch H G. All-cause mortality in randomized trials of cancer screening. J Natl Cancer Inst 2002; 94: 167-73.

10 Lauer M S, Blackstone E H, Young J B, Topol E J. Cause of death in clinical research: Time for a reassessment? J Am Coll Cardiol 1999; 34: 618-20.

\section{SUPPORTING INFORMATION}

Additional Supporting Information may be found in online version of this article.

Fig. S1. All-cause mortality of esophageal cancer patients undergoing pathologic staging after receiving neoadjuvant therapy. Vertical bars on Kaplan-Meier estimates represent $68 \%$ confidence limits, equivalent to \pm 1 standard error.

Fig. S2. Instantaneous risk of death (hazard function). Dashed lines represent $68 \%$ confidence limits.

Fig. S3. Survival by number of cancer-positive locoregional lymph nodes. Format is as in Fig. 1. A. Squamous cell carcinoma. B. Adenocarcinoma.

Fig. S4. Survival by histologic grade (G1, well differentiated; G2, moderately differentiated; G3, poorly differentiated; G4, undifferentiated). Format is as in Fig. 1. A. Squamous cell carcinoma. B. Adenocarcinoma.

Fig. S5. Survival by upper extent of cancer in the esophagus (location: upper, middle, lower). Format is as in Fig. 1. A. Squamous cell carcinoma. B. Adenocarcinoma.

Fig. S6. Survival by patient age $(<60,60-70$, $>70$ years). Format is as in Fig. 1. A. Squamous cell carcinoma. B. Adenocarcinoma.

Fig. S7. Survival by sex. Format is as in Fig. 1. A. Squamous cell carcinoma. B. Adenocarcinoma.

Fig. S8. Survival by type of neoadjuvant therapy. Format is as in Fig. 1. A. Squamous cell carcinoma. B. Adenocarcinoma.

Fig. S9. Survival by use of adjuvant therapy. Format is as in Fig. 1. A. Squamous cell carcinoma. B. Adenocarcinoma.

Fig. S10. Survival by number of regional lymph nodes resected. Format is as in Fig. 1. A. Squamous cell carcinoma. B. Adenocarcinoma.

(C) 2016 International Society for Diseases of the Esophagus 
Fig. S11. Survival by resection margin (R0, cancer-free; R1, microscopic; R2, macroscopic). Format is as in Fig. 1. A. Squamous cell carcinoma. B. Adenocarcinoma.

Table S1. Characteristics of patients receiving neoadjuvant therapy for adenosquamous and undifferentiated carcinoma of the esophagus

Table S2. Treatment received by patients with adenosquamous and undifferentiated carcinoma of the esophagus

Table S3. Pathologic cancer categories of patients receiving neoadjuvant therapy for adenosquamous and undifferentiated carcinoma of the esophagus

\section{APPENDIX : Worldwide Esophageal Cancer Collaboration: participating institutions and investigators}

\begin{tabular}{|c|c|c|}
\hline Institution & Location & Investigators \\
\hline $\begin{array}{l}\text { Beijing Cancer } \\
\text { Hospital, Peking } \\
\text { University }\end{array}$ & Beijing, China & Ken N. Chen \\
\hline Cleveland Clinic & $\begin{array}{l}\text { Cleveland, OH; } \\
\text { USA }\end{array}$ & $\begin{array}{c}\text { Thomas W. Rice } \\
\text { Eugene H. } \\
\text { Blackstone }\end{array}$ \\
\hline $\begin{array}{l}\text { Case Western } \\
\text { Reserve } \\
\text { University }\end{array}$ & $\begin{array}{l}\text { Cleveland, OH; } \\
\text { USA }\end{array}$ & $\begin{array}{l}\text { Carolyn } \\
\text { Apperson- } \\
\text { Hansen }\end{array}$ \\
\hline $\begin{array}{l}\text { Erasmus Medical } \\
\text { Center }\end{array}$ & $\begin{array}{l}\text { Rotterdam, The } \\
\text { Netherlands }\end{array}$ & $\begin{array}{c}\text { Bas P.L. Wijnhoven } \\
\text { Jan van Lanschot } \\
\text { Sjoerd Lagarde }\end{array}$ \\
\hline $\begin{array}{l}\text { Fourth Hospital of } \\
\text { Hebei Medical } \\
\text { University }\end{array}$ & $\begin{array}{l}\text { Shijiazhuang, } \\
\text { Hebei; China }\end{array}$ & Jun-Feng Liu \\
\hline $\begin{array}{l}\text { Fox Chase Cancer } \\
\text { Center }\end{array}$ & $\begin{array}{l}\text { Philadelphia, PA; } \\
\text { USA }\end{array}$ & $\begin{array}{l}\text { Walter J. Scott } \\
\text { Donna } \\
\text { Edmondson }\end{array}$ \\
\hline $\begin{array}{l}\text { Groote Schuur } \\
\text { Hospital, } \\
\text { University of } \\
\text { Cape Town }\end{array}$ & $\begin{array}{l}\text { Cape Town; South } \\
\text { Africa }\end{array}$ & Riette Burger \\
\hline $\begin{array}{l}\text { Guy's \& St } \\
\text { Thomas' } \\
\text { Hospitals }\end{array}$ & London, UK & $\begin{array}{c}\text { Andrew R. Davies } \\
\text { Janine Zylstra }\end{array}$ \\
\hline $\begin{array}{l}\text { Helsinki University } \\
\text { Hospital }\end{array}$ & Helsinki; Finland & $\begin{array}{l}\text { Jari V. Räsänen } \\
\text { Jarmo A. Salo } \\
\text { Yvonne } \\
\text { Sundstrom }\end{array}$ \\
\hline $\begin{array}{l}\text { Hospital Universi- } \\
\text { tario del Mar }\end{array}$ & Barcelona; Spain & Manuel Pera \\
\hline Hôpital Nord & Marseille; France & Xavier B. D'Journo \\
\hline $\begin{array}{c}\text { Indiana University } \\
\text { Medical Center }\end{array}$ & $\begin{array}{l}\text { Indianapolis, IN; } \\
\text { USA }\end{array}$ & Kenneth A. Kesler \\
\hline $\begin{array}{l}\text { University of Texas } \\
\text { MD Anderson } \\
\text { Hospital }\end{array}$ & Houston, TX; USA & $\begin{array}{l}\text { Wayne L. Hofstetter } \\
\text { Arlene Correa } \\
\text { Stephen G. } \\
\text { Swisher }\end{array}$ \\
\hline
\end{tabular}

(Continued)
Appendix (Continued)

\begin{tabular}{|c|c|c|}
\hline Mayo Clinic & $\begin{array}{l}\text { Rochester, MN; } \\
\text { USA }\end{array}$ & Mark S. Allen \\
\hline $\begin{array}{l}\text { Medical University } \\
\text { of South } \\
\text { Carolina }\end{array}$ & $\begin{array}{l}\text { Charleston, SC; } \\
\text { USA }\end{array}$ & Chad E. Denlinger \\
\hline $\begin{array}{l}\text { Memorial Sloan- } \\
\text { Kettering Cancer } \\
\text { Center }\end{array}$ & $\begin{array}{l}\text { New York, NY; } \\
\text { USA }\end{array}$ & Valerie W. Rusch \\
\hline $\begin{array}{l}\text { University of } \\
\text { Queensland, } \\
\text { Princess Alexan- } \\
\text { dra Hospital }\end{array}$ & Brisbane; Australia & $\begin{array}{l}\text { B. Mark Smithers } \\
\text { David Gotley } \\
\text { Andrew Barbour } \\
\text { Iain Thomson }\end{array}$ \\
\hline $\begin{array}{l}\text { University of New- } \\
\text { castle upon Tyne }\end{array}$ & $\begin{array}{l}\text { Newcastle upon } \\
\text { Tyne; UK }\end{array}$ & $\begin{array}{l}\text { S. Michael Griffin } \\
\text { Jon Shenfine }\end{array}$ \\
\hline $\begin{array}{l}\text { Oregon Health \& } \\
\text { Science } \\
\text { University }\end{array}$ & Portland, OR; USA & $\begin{array}{l}\text { Paul H. Schipper } \\
\text { John G. Hunter }\end{array}$ \\
\hline $\begin{array}{l}\text { Royal Marsden } \\
\text { NHS Foundation } \\
\text { Trust }\end{array}$ & London; UK & William H. Allum \\
\hline $\begin{array}{l}\text { Shanghai Chest } \\
\text { Hospital }\end{array}$ & Shanghai; China & $\begin{array}{l}\text { Wentao (Vincent) } \\
\text { Fang }\end{array}$ \\
\hline $\begin{array}{l}\text { Toronto General } \\
\text { Hospital }\end{array}$ & $\begin{array}{l}\text { Toronto, ON; } \\
\text { Canada }\end{array}$ & Gail E. Darling \\
\hline $\begin{array}{l}\text { University Zeiken- } \\
\text { huizen Leuven }\end{array}$ & Leuven; Belgium & $\begin{array}{l}\text { Tony E.M.R. Lerut } \\
\text { Phillipe R. } \\
\text { Nafteux }\end{array}$ \\
\hline $\begin{array}{l}\text { University Medical } \\
\text { Center Utrecht }\end{array}$ & $\begin{array}{l}\text { Utrecht, The } \\
\text { Netherlands }\end{array}$ & $\begin{array}{l}\text { Richard van } \\
\text { Hillegersberg }\end{array}$ \\
\hline $\begin{array}{l}\text { University of } \\
\text { Alabama at } \\
\text { Birmingham }\end{array}$ & $\begin{array}{l}\text { Birmingham, AL; } \\
\text { USA }\end{array}$ & Robert J. Cerfolio \\
\hline $\begin{array}{l}\text { Hospital de } \\
\text { Clinicas, } \\
\text { University of } \\
\text { Buenos Aires }\end{array}$ & $\begin{array}{c}\text { Buenos Aires; } \\
\text { Argentina }\end{array}$ & $\begin{array}{l}\text { Luis Durand } \\
\text { Roberto De } \\
\text { Antón }\end{array}$ \\
\hline $\begin{array}{l}\text { The University of } \\
\text { Chicago, Depart- } \\
\text { ment of Surgery }\end{array}$ & Chicago, IL; USA & Mark K. Ferguson \\
\hline $\begin{array}{l}\text { University of Hong } \\
\text { Kong Medical } \\
\text { Center, Queen } \\
\text { Mary Hospital }\end{array}$ & Hong Kong; China & Simon Law \\
\hline $\begin{array}{l}\text { University of } \\
\text { Michigan }\end{array}$ & $\begin{array}{l}\text { Ann Arbor, MI; } \\
\text { USA }\end{array}$ & $\begin{array}{l}\text { Mark B. Orringer } \\
\text { Becky L. } \\
\text { Marshall }\end{array}$ \\
\hline $\begin{array}{l}\text { University of } \\
\text { Montreal }\end{array}$ & $\begin{array}{l}\text { Montreal, Quebec; } \\
\text { Canada }\end{array}$ & $\begin{array}{c}\text { André Duranceau } \\
\text { Susan Howson }\end{array}$ \\
\hline $\begin{array}{l}\text { University of Pitts- } \\
\text { burgh Medical } \\
\text { Center }\end{array}$ & $\begin{array}{l}\text { Pittsburgh, PA; } \\
\text { USA }\end{array}$ & $\begin{array}{l}\text { James D. Luketich } \\
\text { Arjun Pennathur } \\
\text { Kathy Lovas }\end{array}$ \\
\hline $\begin{array}{l}\text { University of } \\
\text { Rochester }\end{array}$ & $\begin{array}{l}\text { Rochester, NY; } \\
\text { USA }\end{array}$ & Thomas J. Watson \\
\hline $\begin{array}{l}\text { University of São } \\
\text { Paulo }\end{array}$ & São Paulo; Brazil & Ivan Cecconello \\
\hline $\begin{array}{l}\text { West China Hospi- } \\
\text { tal of Sichuan } \\
\text { University }\end{array}$ & $\begin{array}{l}\text { Chengdu, Sichuan; } \\
\text { China }\end{array}$ & Long-Qi Chen \\
\hline
\end{tabular}

Ann Arbor, MI

Becky L.

Marshall

Montreal, Quebec;

mes D. Luketich

Arjun Pennathur

Kathy Lovas

University of

Rochester

USA

Chengdu, Sichuan; Long-Qi Chen 